Int. J. Morphol.,

33(3):1114-1119, 2015.

\title{
Proximal Femoral Epiphysis: Manual Morphometry versus Digital Morphometry
}

\author{
Epífisis Femoral Proximal: Morfometría Manual versus Morfometría Digital
}

Tamires Meira Menezes*; Taciano Dias de Souza Rocha**; Belisa Duarte Ribeiro de Oliveira***; Yuri Mateus Lima de Albuquerque ${ }^{* * * * *}$ \& Vitor Caiaffo ${ }^{* * * * * *}$

MENEZES, T. M.; ROCHA, T. D. S.; DE OLIVEIRA, B. D. R.; DE ALBUQUERQUE, Y. M. L. \& CAIAFFO, V. Proximal femoral epiphysis: Manual morphometry versus digital morphometry. Int. J. Morphol., 33(3):1114-1119, 2015.

SUMMARY: It is important and necessary to know the morphometric characteristics of the proximal femur in order to reduce the risk of complications associated with surgical procedures performed in the area due to vascular, metabolic or trauma causes, and to achieve an alignment of prosthesis to be implanted. The morphometric analysis has proved possible to be used, and can be a valid help to obtain certain parameters that may contribute to scientific research in several areas. For this, a good understanding of evaluation techniques and principles that can be applied to obtain reliable and valid results is needed. To measure the proximal femoral epiphysis by manual morphometry, with the aid of the caliper, and digital morphometry, with the aid of software and compare them. Twenty nine femurs were used to measure the following parameters: diameter of the femoral head in the cranio caudal axis (DFH-CC) and sagittal axis (DFH-S), diameter of the femoral neck cranio caudal axis (DFN-CC) and sagittal axis (DFN-S), length of the femoral neck (LFN) and length of the intertrochanteric line (LIL). After the measurements, the mean values were compared between the two morphometric techniques. The manual morphometry obtained the following average values: DFH-CC 4.42 \pm 0.44 , DFH-S 4.38 \pm 0.47 ; DFN-CC 3.10 \pm 0.35 ; DFN-S 2.50 \pm 0.37 ; LFN 2.55 \pm 0.42 ; LIL 4.79 \pm 0.62 . While the values obtained by digital morphometry were: DFH-CC 3.09 \pm 0.41 , DFH-S 3.35 \pm 0.40 ; DFN-CC 1.79 \pm 0.26 ; DFN-S 2.26 \pm 0.23 ; LFN 1.42 \pm 0.33 ; LIL 3.33 \pm 0.54 . All parameters measured from the manual technique showed values significantly higher $(\mathrm{p}<0.05)$ than values obtained by digital morphometry. This study showed that there is no morphometry gold standard. Different morphometric methods can effectively reproduce, the values of morphometric anatomical structures, depending on the purpose of the study, the anatomical structures and experience of the researcher.

KEY WORDS: Proximal femoral epiphysis; Morphometry; Anatomy.

\section{INTRODUCTION}

The femur is the longest bone in the human body being composed at the proximal end by the head, the anatomical neck (attaching the head to the trochanters), the major and minor trochanters (which serve as the site of insertion of muscles) and the surgical neck, joining the diaphysis the proximal epiphysis femur (Mourão \& Vasconcellos, 2001). It is the typical bone of the lower limb extending from the pelvis to the knee. The femur forms the skeleton of the thigh, carries the body weight, supports the movement of the legs, provides attachment for muscles, stores blood cells, calcium and phosphate (Chowdhury et al., 2013).

It is important and indispensable to know the morphometric characteristics of the proximal femur, with the intent of minimizing the risk of complications related to surgical procedures executed in the area due to vascular, traumatic or metabolic causes, and to achieve an alignment of prosthesis to be implanted (Mahaisavariya et al., 2002). Morphometric studies of the proximal femur were performed in different populations and communities (Mahaisavariya et al.; El-Kaissi et al., 2005). The data obtained from these studies demonstrated that femoral morphometry had regional features and social differences.

An investigation of the morphometric characteristics of the proximal femur in dry bones, comprehensive studies and standardization of data for a study population is of great importance for the

* Department of Pathology, Universidade Federal de Pernambuco, Recife, Brazil.

** Department of Physiotherapy, Universidade Federal de Pernambuco, Recife, Brazil.

*** Department of Physiotherapy, ASCES, Caruaru, Brazil.

***** Department of Biology, Universidade Federal Rural de Pernambuco, Recife, Brazil.

****** Department of Animal Morphology and Physiology, Universidade Federal Rural de Pernambuco, Recife, Brazil. 
determination of risk factors in pathological conditions, for preoperative planning and design of components of prostheses (Noble et al., 1988; Rubin et al., 1992; Chin et al., 1997; Bergot et al., 2002; Khang et al., 2003; Irdesel \& Ari, 2006; Atilla et al., 2007).

Methods and techniques, with the support of various technological resources in the basic sciences, such as morphology, are widely used. These methods are extremely important for a better understanding of diseases such as osteoporosis, fractures, and the creation of more appropriate therapies (Casanova et al., 2006).

Morphometry is the quantitative description of geometrical structures of findings of any extent (Meijer $e t$ al., 1997; Buhmeida, 2006). This includes the flatness, which is the process of measuring horizontal, which means, the extent of the areas of the flat surfaces, and the stereochemistry that is related to the extent of the solid (Meijer et al.). According with de Andrea et al. (2008), morphometric analysis has proved possible to be applied, may constitute an auxiliary to obtain certain parameters that can contribute to scientific research in several areas too. For this, a good understanding of valuation techniques and principles that can be applied to obtain reliable and valid results is required. The morphometric measurement is to obtain measurements collected from symmetric body parts in order to establish the proportions of the body and determine the constitutional morphological type (Freitas, 2004). Based on the results of the measurements, it is possible to establish strategies for ergonomic action, therapeutic, diagnostic or prognostic (Gogia et al., 1987; Yaikwawongs et al., 2009).

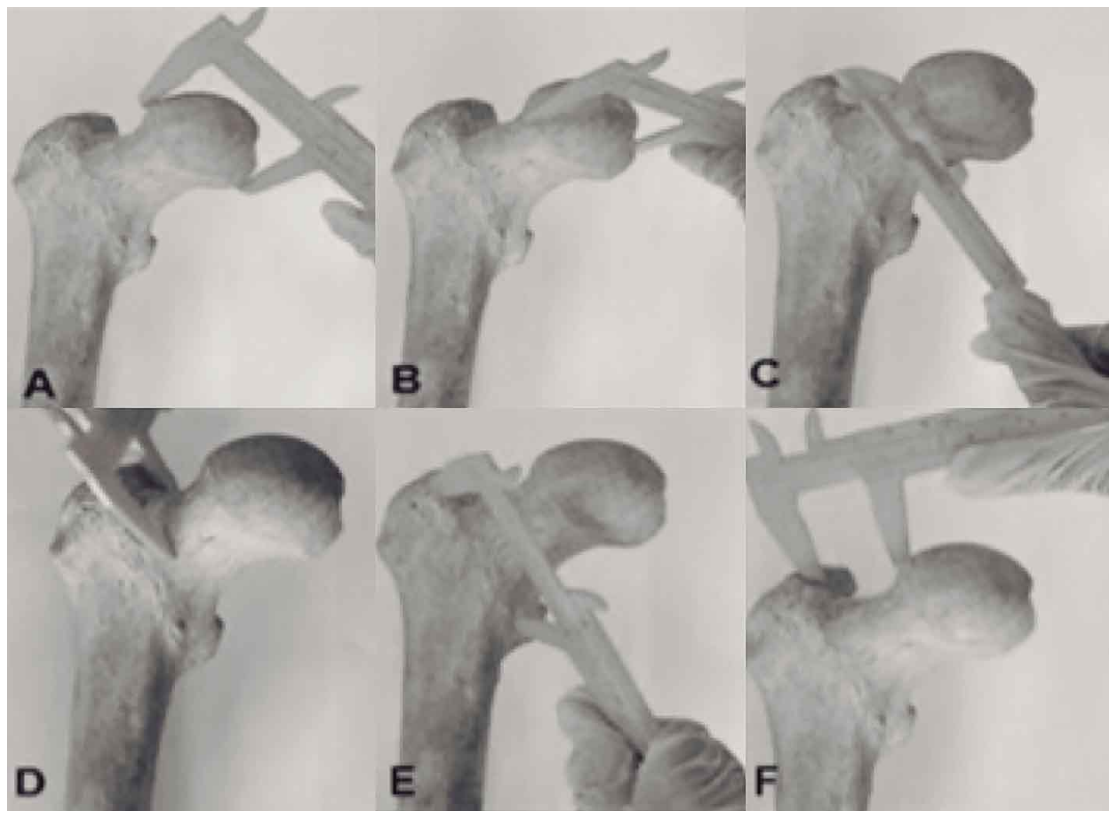

Thus, the objective of this study measured parameters of the proximal femoral epiphysis through technical manual morphometry, with the aid of calipers and digital morphometry technique with the aid of software ImageJ ${ }^{\circledR}$ and then compared them.

\section{MATERIAL AND METHOD}

Twenty nine (29) dried femurs from cadavers were used, 18 left and 11 right, belonging to the collection of the Department of Anatomy of the Federal University of Pernambuco (UFPE) and the Department of Animal Morphology and Physiology (DMFA) of the Federal Rural University of Pernambuco (UFRPE).

The morphometry consisted of the following parameters: DFH - diameter of the femoral head in the cranio caudal axis (distance in a straight line from the upper end to the lower end of the femoral head) and sagittal axis (distance in a straight line from the front end behind end of the femoral head); DFN - diameter of the femoral neck in a cranio caudal axis (distance in a straight line from the upper end to the lower end of the anatomical neck of the femur) and sagittal axis (distance in a straight line, the front end to the rear end of the lap anatomy of the femur); LFN- length of the femoral neck (distance in a straight line between the lower region of the femoral head and the base of the greater trochanter) and LIL - length of the intertrochanteric line (distance in a straight line joining the highest point of trochanters highest and lowest previously (Mourao \& Vasconcellos; Murlimanju et al.; Iyem et al., 2013).
Fig. 1. Images from manual measurements with the aid of calipers. A) diameter of the femoral head in the cranio caudal axis; B) diameter of the femoral head on sagittal axis; C) diameter of the femoral neck in a cranio caudal axis; D) diameter of the femoral neck in a sagittal axis; E) length of the intertrochanteric line; F) length of the femoral neck. 


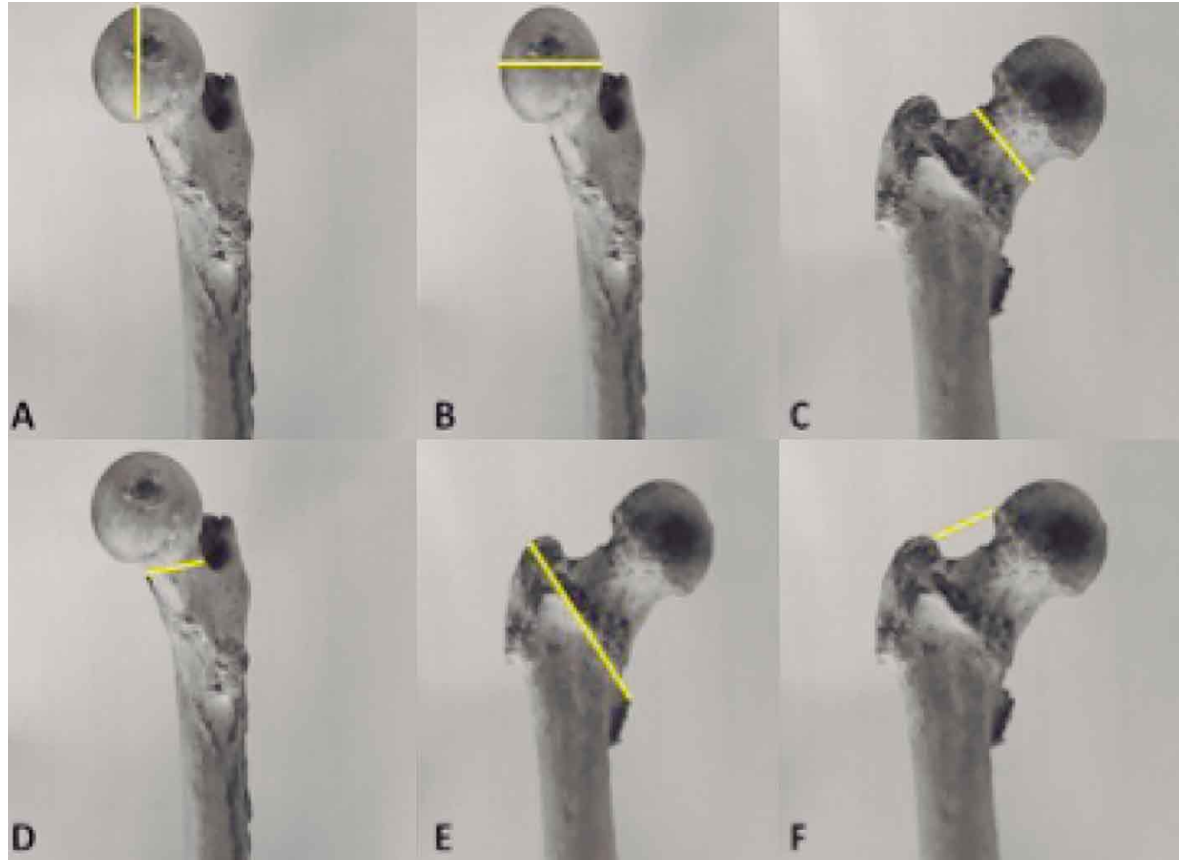

Fig. 2.- Images from the measurements performed with the ImageJ (B) software. A) diameter of the femoral head in the superior-inferior axis; B) diameter of the femoral head on anteroposterior axis; C) diameter of the femoral neck in a superior-inferior axis; D) diameter of the femoral neck in a anteroposterior axis; E) length of the intertrochanteric line; F) length of the femoral neck. to $1 \mathrm{~cm}$. Three analyzes for each variable were performed on both methods, always by the same person, and from the results calculated an arithmetic average. Data were tabulated in Microsoft Office Excel 2010 software (Microsoft Corp.). Then, statistical analysis was performed using the Graphpad Prism software 6, using the KolmogorovSmirnov and the mean comparison with the Student t test.
Initially, the samples were measured with the aid of the caliper (Fig. 1) and then were photographed by a digital camera (INTOVA IC 500®) at a distance of $50 \mathrm{~cm}$ in height relative to the proximal femoral epiphysis attached by a stalk iron. Then, the images were transferred to a microcomputer for processing with the aid of Image $₫$ software and from this calculated the dimensions pre-established for the study (Fig. 2). The scanned images were measured in feet, converted from pixels, 78 pixels on the scale corresponded

\section{RESULTS}

The present study, using both manual morphometry technique with the assistance of calipers, as using the Image ${ }^{\circledR}$ software, showed statistical difference in all parameters evaluated. All measurements taken with the caliper showed values significantly higher than the values obtained with the measurement using the software (Table I).

Table I. Values in centimeters $(\mathrm{cm})$, measured through the techniques of measurement with calipers and the Image ${ }^{\circledR}$ software parameters. Values expressed as Mean \pm Standard deviation.

\begin{tabular}{lccc}
\hline Parameters & Caliper & Sof tware Image J & $\boldsymbol{p}$ \\
\hline DFH - cranio caudal axis & $4.42 \pm 0.44$ & $3,09 \pm 0.41$ & $p<0.0001^{*}$ \\
DFH - sagital axis & $4.38 \pm 0.47$ & $3.35 \pm 0.40$ & $p<0.0001^{*}$ \\
DFN - cranio caudal axis & $3.10 \pm 0.35$ & $1.79 \pm 0.26$ & $p<0.0001^{*}$ \\
DFN - sagital axis & $2.50 \pm 0.37$ & $2.26 \pm 0.23$ & $p=0.0017^{*}$ \\
LFN & $2.55 \pm 0.42$ & $1.42 \pm 0.33$ & $p<0.0001^{*}$ \\
LIL & $4.79 \pm 0.62$ & $3.33 \pm 0.54$ & $p<0.0001^{*}$ \\
\hline
\end{tabular}

$*=$ Statistical difference between the measurements with the caliper and the Image J® software. The KolmogorovSmirnov and t-Student test. DFH= diameter femoral head test; DFN= Diameter of the femoral neck; LFN= Length of femoral neck; LIL= Length of the intertrochanteric line. 


\section{DISCUSSION}

Murlimanju et al. (2012) working with the calipers, have found values similar to this present study, for example: this work has obtained the average to the diameter of the femoral head (sagittal axis) of $4.38 \mathrm{~cm}$, while the average found by the aforementioned authors was $4.15 \mathrm{~cm}$. With respect to the diameter of the femoral neck (cranio caudal axis), the present study obtained an average of $3.09 \mathrm{~cm}$ and Murlimanjur et al., have obtained an average value of 3.02. Which means, very similar values. In morphometry several factors must be considered, which are related to the final dissonance results, such as ethnicity, age, sex and environmental influences. Murlimanju et al. in their studies, have used bones belonging to the Indian population and performed their measurements with the aid of the caliper. These authors found no significant difference between the right and left femurs. Probably due to the bones belonging to a homogeneous population. These values differ slightly from our results and this can be explained by the large heterogeneity of our population, which is a possibility of closeness between the populations studied and also because we have not identified and separated the corpse pieces measured by age, sex and ethnicity. Corroborating these results, Osorio et al. (2012) have analyzed the proximal femoral epiphysis of the Chilean population, using as a tool the caliper, and did not achieve significant differences between the right and left bones. These authors used a homogeneous population, demonstrating again that factors such as ethnicity and environmental influences may interfere with bone measurements. Take into consideration the ethnic characteristics in morphometric analysis is important because populations of certain regions suffer peculiar adaptations due to different eating habits, sports, weather and these characteristics may influence the body projection, where regions with similar properties may exhibit particular morphological characteristics. Thus, it can be inferred that the method of manual morphometry, with the aid of calipers, can be considered as an effective technique, taking into account intrinsic (anatomical) and extrinsic variations (age, sex, ethnicity and environmental influence) in corpse pieces studied.

Several authors have found through their work the applicability of the software in morphometric studies. Miot \& Brianezi (2010) have analyzed the density and intensity of dermal collagen fibers using Image ${ }^{\circledR}$ software. According to these authors, computational systems should be used for quantitative analysis in dermatological research, qualitative, biochemical and biomechanical techniques. Wu \& Bogie (2009) have used a single method and compared different software: Image $\AA$ and $\mathrm{VeVMD} \AA$ for measurements of crosssectional area of the gluteus maximus. Performed the measurements, these authors concluded that the use of Image $₫$ program is more suitable to obtain more reliable results. The VeVMD® mold requires a square of known size to quantify the image presenting a potential source of error, not necessarily found with Image ${ }^{\circledR}$, which automatically reads the conversion pixels. The ImageJ ${ }^{\circledR}$ also has more flexibility in processing and analysis of images features, such as the potential to apply a limit based on gray levels. Since different tissues have different gray levels to the computer, the Image ${ }^{\circledR}$ can be used to target and choose the tissue of interest via computer algorithms. The present study used the Image $\triangle \circledR$ software, and obtained the values listed in Table I. Iyem et al., analyzing contralateral proximal femoral epiphysis in patients with total prosthesis hip, radiographs used as sources of images that were subsequently digitized and measured by Sectra PACS $®$ software. These authors found significant differences between men and women in diameter parameters of the femoral head, femoral neck width, length of the femoral neck and the length of the intertrochanteric line. Comparing these parameters, we find different values for the same parameters. This difference can be explained by the probable age range, sex and ethnicity of corpse pieces and also some distortion related to the digitization of images for later analysis in such software as well as the proper tools for each software.

Some studies make use of techniques of morphometry comparison with the aim of trying to establish that the most effective and closer to the true values. When comparing the values obtained with different measurement techniques, this paper has obtained significant differences in all parameters of the proximal femoral epiphysis (Table I). Similar to our study, Mkandawire et al. (2005) have studied through the caliper and Scion Image Beta 4.0.2 Win ${ }^{\circledR}$ software, the crosssection and length of the ligaments of the foot and ankle. The ligaments were subjected to a technique named freeze fracture to be photographed and subsequently measured in the software. Comparing the data with both techniques concluded that the technique, using software, is more faithful to the real values when compared with the manual method. These authors assume that when the ligaments are measured by caliper, there will be a decrease and/or increase the real value of such structures on the grounds of errors inherent to the evaluator, thus resulting in an underestimation and/or overestimation of systemic results. Furthermore, the software method is easier to evaluate the morphology of the ligaments. However, the bones are three dimensional structures formed by some protrusions, projections and apertures called bone injury. The digital measurement use one-dimensional images, putting possibly at risk, the full accuracy of the results. 


\section{CONCLUSION}

The results of morphometric measurements in the chosen techniques are conditioned to the method chosen, compliance and experience of the evaluator, intrinsic characteristics of the anatomic article like anatomical variations, as well as extrinsic factors such as age, sex, ethnicity, and environmental influences.

Thus, the present study has demonstrated that there is no "gold standard" morphometry, but different methods that can faithfully reproduce the morphometric values of anatomical structures, depending on the purpose of the research, the anatomical structures and experience of the researcher.

MENEZES, T. M.; ROCHA, T. D. S.; DE OLIVEIRA, B. D. R.; DE ALBUQUERQUE, Y. M. L. \& CAIAFFO, V. Epífisis femoral proximal: Morfometría manual versus la morfometría digital. Int. J. Morphol., 33(3):1102-1107, 2015.

RESUMEN: Es importante y necesario conocer las características morfométricas del fémur proximal con el fin de reducir el riesgo de complicaciones asociadas con los procedimientos quirúrgicos realizados en la zona debido a causas vasculares, metabólicas o traumáticas y para lograr una alineación de prótesis para ser implantada. El análisis morfométrico ha demostrado que es posible utilizar, y puede ser una ayuda válida para obtener ciertos parámetros que pueden contribuir a la investigación científica en diversas áreas. Para ello, se necesita un buen conocimiento de las técnicas de evaluación y los principios que se pueden aplicar para obtener resultos fiables y válidos. El objetivo fue medir la epífisis femoral proximal mediante morfometría manual mediante la ayuda de pinza y compararla con la morfometría digital mediante software . Veintinueve fémures fueron utilizados para medir los siguientes parámetros: diámetro de la cabeza femoral en el eje cráneo-caudal (DFH-CC) y eje sagital (DFH-S), diámetro del eje cráneo-caudal del cuello femoral (DFN-CC) y eje sagital (DFN-S), longitud del cuello femoral (LFN) y la longitud de la línea intertrocantérica (LIL). Después de las mediciones, los valores medios se compararon entre las dos técnicas morfométricas. La morfometría manual obtuvo los siguientes valores medios: DFH-CC 4,42 $\pm 0,44$, DFH-S 4,38 $\pm 0,47$; DFN-CC

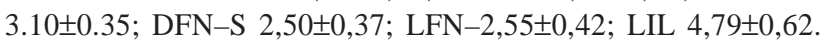
Mientras que los valores obtenidos por la morfometría digitales fue-

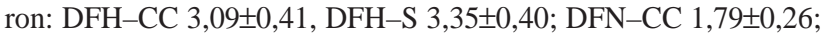
DFN-S 2,26 $\pm 0,23$; LFN 1,42 $\pm 0,33$; LIL 3,33 $\pm 0,54$. Todos los parámetros medidos de la técnica manual mostraron valores significativamente mayores $(\mathrm{p}<0,05)$ que los valores obtenidos por morfometría digital. Este estudio mostró que no existe un estándar en morfometría. Diferentes métodos morfométricos pueden reproducir de manera efectiva los valores de las estructuras anatómicas morfométricas, dependiendo del propósito del estudio, de las estructuras anatómicas y la experiencia del investigador.

PALABRAS CLAVE: Epífisis femoral proximal; Morfometría; Anatomía.

1118

\section{REFERENCES}

Atilla, B.; Oznur, A.; Cag ${ }^{`}$ lar, O.; Tokgözog $`$ lu, M. \& Alpaslan, M. Osteometry of the femora in Turkish individuals: a morphometric study in 114 cadaveric femora as an anatomic basis of femoral component design. Acta Orthop. Traumatol. Turc., 41(1):64-8, 2007.

Buhmeida, A. Quantitative pathology: historical background, clinical research and application of nuclear morphometry and DNA image cytometry. Libyan J. Med., 1(2):126-39, 2006.

Bergot, C.; Bousson, V.; Meunier, A.; Laval-Jeantet, M. \& Laredo, J. D. Hip fracture risk and proximal femur geometry from DXA scans. Osteoporos. Int., 13(7):542-50, 2002.

Chin, K.; Evans, M. C.; Cornish, J.; Cundy, T. \& Reid, I. R. Differences in hip axis and femoral neck length in premenopausal women of Polynesian, Asian and European origin. Osteoporos. Int., 7(4):344-7, 1997.

Chowdhury, S.; Naushaba, H.; Begum, J.; Ahmed, S.; Khan, L. F.; Parash, T. H. \& Qashem, R. Morphometrical and topographical anatomy of position of nutrient foramen on fully ossified left femur. Delta Med. Coll. J., 1(1):13-5, 2013.

Casanova, M. S.; Ortega, A. I.; Haiter-Neto, F. \& Almeida, S. M. Análise comparativa da maturação óssea determinada pelo método de Grave-Brown entre imagens convencionais e digitalizadas. Rev. Dent. Press Ortodon. Ortop. Facial, 11(5):104-9, 2006.

de Andrea, C. E.; Bleggi-Torres, L. F. \& Alves, M. T. S. Análise da morfometria nuclear: descrição da metodologia e o papel dos softwares de edição de imagem. J. Bras. Patol. Med. Lab., 44(1):51-7, 2008.

El-Kaissi, S.; Pasco, J. A.; Henry, M. J.; Panahi, S.; Nicholson, J. G.; Nicholson, G. C. \& Kotowicz, M. A. Femoral neck geometry and hip fracture risk: the Geelong osteoporosis study. Osteoporos. Int., 16(10):1299-303, 2005.

Freitas, V. Anatomia - Conceitos e Fundamentos. São Paulo, Artmed, 2004.

Gogia, P. P.; Braatz, J. H.; Rose, S. J. \& Norton, B. J. Reliability and validity of goniometric measurements at the knee. Phys. Ther., 67(2):192-5, 1987.

Irdesel, J. \& Ari, I. The proximal femoral morphometry of Turkish women on radiographs. Eur. J. Anat., 10(1):21-6, 2006.

Iyem, C.; Güvencer, M.; Karatosun, V. \& Unver, B. Morphometric evaluation of proximal femur in patients with unilateral total hip prosthesis. Clin. Anat., 27(3):478-88, 2013.

Khang, G.; Choi, K.; Kim, C. S.; Yang, J. S. \& Bae, T. S. A study of Korean femoral geometry. Clin. Orthop. Relat. Res., (406):11622, 2003. 
MENEZES, T. M.; ROCHA, T. D. S.; DE OLIVEIRA, B. D. R.; DE ALBUQUERQUE, Y. M. L. \& CAIAFFO, V. Proximal femoral epiphysis: Manual morphometry versus digital morphometry. Int. J. Morphol., 33(3):1114-1119, 2015

Mahaisavariya, B.; Sitthiseripratip, K.; Tongdee, T.; Bohez, E. L.; Vander Sloten, J. \& Oris, P. Morphological study of the proximal femur: a new method of geometrical assessment using 3-dimensional reverse engineering. Med. Eng. Phys., 24(9):617-22, 2002.

Meijer, G. A.; Beliën, J. A.; van Diest, P. J. \& Baak, J. P. Origins of ... image analysis in clinical pathology. J. Clin. Pathol., 50(5):36570, 1997.

Miot, H. A. \& Brianezi, G. Morphometric analysis of dermal collagen by color clusters segmentation. An. Bras. Dermatol., 85(3):3614, 2010.

Mkandawire, C.; Ledoux, W. R.; Sangeorzan, B. J. \& Ching, R. P. Foot and ankle ligament morphometry. J. Rehabil. Res. Dev., 42(6):809-20, 2005.

Mourão, A. L. \& Vasconcellos, H. A. Geometria do fêmur proximal em ossos de brasileiros. Acta Fisiatr., 8(3):113-9, 2001.

Murlimanju, B. V.; Prabhu, L. V.; Pai, M. M.; Kumar, B. M.; Dhananjaya, K. V. N. \& Prashanth, K. U. Osteometric study of the upper end of femur and its clinical applications. Eur. J. Orthop. Surg. Traumatol., 22(3):227-30, 2012.

Noble, P. C.; Alexander, J. W.; Lindahl, L. J.; Yew, D. T.; Granberry, W. M. \& Tullos, H. S. The anatomic basis of femoral component design. Clin. Orthop. Relat. Res., (235):148-65, 1988.

Osorio, H.; Schorwer, K.; Coronado, C.; Delgado, J. \& Aravena P. Proximal Femoral Epiphysis Anatomy in Chilean Population. Orthopedic and Forensic Aspects. Int. J. Morphol., 30(1):258$62,2012$.

Rubin, P. J.; Leyvraz, P. F.; Aubaniac, J. M.; Argenson, J. N.; Estève, P. \& de Roguin, B. The morphology of the proximal femur. A three-dimensional radiographic analysis. J. Bone Joint Surg. Br., 74(1):28-32, 1992.

Wu, G. A. \& Bogie, K. Assessment of gluteus maximus muscle area with different image analysis programs. Arch. Phys. Med. Rehabil., 90(6):1048-54, 2009.

Yaikwawongs, N.; Limpaphayom, N. \& Wilairatana, V. Reliability of digital compass goniometer in knee joint range of motion measurement. J. Med. Assoc. Thai., 92(4):517-22, 2009.

\author{
Correspondence to: \\ Vitor Caiaffo \\ Department of Animal Morphology and Physiology \\ Universidade Federal Rural de Pernambuco \\ Rua Marquês do Paraná, 160 - Ap. 1202 \\ ZIP: 52021-050 \\ Espinheiro \\ Recife/PE \\ BRAZIL
}

Email: vitorcaiaffo@dmfa.ufrpe.br

Received: 14-08-2014

Accepted: 17-07-2015 